county consultants, treatment carried out by the practitioner under this scheme will be on the efficient lines set out in the League of Nations Committee's recommendations. Indeed it will be to the practitioners' interest to give prolonged treatment on these lines, and although there may be hitches at first, there is good reason for hope that, through this scheme, the standard of treatment throughout the country will eventually be raised substantially above the present.

There is at present an admittedly weak spot in our measures of control; it is the failure to bring under treatment sufficient females ; but for them it would seem reasonable to expect that in spite of war conditions we could begin to hope for a reduction in the incidence of venereal diseases in this country. The conditions favourable to such a desirable result of our efforts are :-

(I) Less than usual traffic with foreign countries.

(2) The relatively low rate of incidence of V.D. (at any rate syphilis) which we had reached in the civil population by the outbreak of the war.

(3) The existing civilian treatment arrangements.

(4) The thorough treatment given to Service cases, thus reducing to a minimum the male carriers in what is now a substantial proportion of the population.

\title{
VIII
}

\section{THE PRESENT TREND OF INCIDENCE OF VENEREAL DISEASES IN ENGLAND AND WALES, AND METHODS OF CONTROL}

Discussion at the Annual General Meeting of the Medical Society for the Study of Venereal Diseases held on July 26th, I94I.

Dr. MARgaret Rorke said that a few days after war was declared she was asked to organise female V.D. Clinics in the County of Hertfordshire, where many women and children had come from evacuated areas. Many infected evacuees were anticipated but next to none were found. It was slow but interesting work to get, not the first clinic, but the other clinics started. Many premises which would have been suitable for a clinic had been taken over as first aid posts, etc. Sometimes it was agreed that the maternity and child welfare centre could be used 
one day a week, but, within a fortnight, in one town where this had been arranged, she was told that on no account should V.D. cases be treated there.

Very few evacuees or transferred patients attended the county clinics. In eighteen months she had had only three women Service patients. Many of the cases seen in country clinics were old neglected syphilis, acquired or congenital.

There were some severe congenital cases also a few recent syphilis infections. The cases of gonorrhœea were mainly the wives of Service men. These men seem to be frequently advised by their medical officers to persuade their wives to go to a clinic. Some men were allowed leave as soon as two weeks after the diagnosis had been made. At least they should have three tests of cure before being allowed to go home.

Infected single girls of good class-girls with steady work and from respectable homes-frequently reported to the panel doctor or to a woman doctor, attended for treatment, and did well. But the low class amateur prostitute still flourished. In war-time the activities of these undesirable and anti-social women should be firmly restricted. On the serious complaint of one or more Service men, they should be compelled to attend for examination and if necessary be treated. Dr. Rorke knew that it was against the voluntary principle, but there was not much voluntaryism left in this country to-day for good citizens. It was neither commonsense nor kind to let these young women remain untreated and continue as a constant focus of infection. It was hateful to see homes embittered and marriages destroyed because a man had sought such companionship. The bitterness of some of the unsophisticated women whose husbands had been infected in this fashion was painful to witness.

Although country, town and rural patients might never reach great numbers none the less they needed treatment, and a number of clinics were necessary, and more sessions must be available than seemed economically justifiable.

Surgeon-Commander D. DunCAN, R.N., said that the more carefully he went through his statistics the more open to inaccuracies he found them to be, but he could give a few figures to show the trend in the Royal Navy. He had taken the personnel in a barracks of about I5,000, and had left out I939 because the very low ratio in that year was due to the large number of young recruits. Syphilis showed a slight increase in I940, reaching a figure of 2 per $\mathrm{I}, 000$, but there was a definite and consistent decrease in gonorrhœa, being 16.6 per 1,000 for I940 from an original figure of $4 \mathrm{I}$ in I934. But all these figures were probably 25 per cent. too high if they were to be taken as representative of the Navy at home as a whole, because the area from which they were selected did not include training establishments where the incidence was very low. With regard to the point made by Dr. Rorke concerning Service men's wives and the question of the men's leave, in the Navy the men were all treated until cured, and they did not get leave until cure was effected.

Surgeon-Lieutenant Genevieve Rewcastle said that in the W.R.N.S., only six cases of infection had occurred. There had been many doubtful infections later established as non-venereal. The distribution of the few cases in the several Commands had been as 


\section{BRITISH JOURNAL OF VENEREAL DISEASES}

even as possible and there was no particularly bad area. Among the measures which, she believed, had helped to keep down the incidence of venereal disease was the avoidance of billetting wherever possible. The girls were placed in established quarters and every effort was made to see that they were properly accommodated. The medical officers saw that quarters fulfilled the standard required. Special attention was given to bathroom and lavatory accommodation. Scrupulous cleanliness was observed with regard to mess traps, clothing, etc. The sister in charge of the sick bay was of great value, and the girls had no hesitation in consulting her about matters concerning which they would feel embarrassment in approaching one of their own officers. Facilities for social intercourse and entertainment were provided. The chief factors to account for the excellent result were the good discipline-which was not over-strict-and the careful supervision of quarters.

Lieut.-Col. T. E. Osmond said that for comparison he would mention a figure he came across by chance of the incidence of venereal disease in a British garrison overseas about the middle of the last century. The ratio per I,000 per annum was just under 700 !

As regards the Army at home, and largely during the war period, a graph of the total cases of venereal diseases month by month produced practically a straight line. The week ending Christmas, r940, showed by far the lowest total of the last 52. But the total number of cases was more important than the ratios. The peace-time Army was a professional Army consisting almost entirely of young unmarried men. Now we had a citizen Army including many men of middle age and married men, and the outlook would be depressing indeed if the incidence of V.D. in the Army to-day were not much lower than in peacetime.

The annual ratios per thousand worked out roughly as follows :

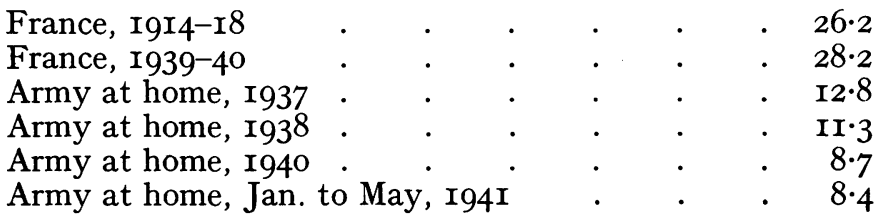

That the present figures showed up so favourably was due, he thought, (I) to the lower incidence of venereal diseases in the civil population, thanks to the working of the clinics; $(2)$ to the greater activity of modern remedies, and (3) to the fact that the present-day soldier was less promiscuous; this was not to say that he was more continent, but he distributed his favours less widely. A very small number of infections (6 per cent.) was due to professional prostitutes ; 80 per cent. of infections were caused by amateurs and I4 per cent. were marital in origin. The ratio of gonorrhœa to syphilis had remained steady at 8 to $\mathrm{I}$. The incidence of venereal diseases expressed in ratios per thousand per month from January, I940, to June, I94I, had been remarkably steady. The peak figure was reached in June, I940, which corresponded with Dunkirk, otherwise the line was almost straight. The figures for June, I94I, compared very well with those for January, I940. The position was almost exactly the same as it had been eighteen months ago. It was known how many cases were 258 
occurring, control was good and tests of cure were rigorous. Most cases were brought under treatment in the early stages ; the Army therefore was not responsible for any great spread of infection, for it was very exceptional for a man to leave the Army in a contagious stage.

With regard to Dr. Rorke's remarks about compulsory treatment of infectious women, this had not been overlooked. On the question of leave, at the beginning of the war there was an order that no soldier who contracted venereal diseases in France should be allowed home for six months, but there were complaints of discrimination and penalties. He was doing his best to see that every man in the Army who suffered from venereal disease was treated in the same way as men suffering from other diseases. A man did not leave hospital until he had had at least one test of cure, and he had three subsequent ones after leaving hospital. The rate of relapse under modern methods of treatment was very small.

Lt.-Col. Letitia FAirfield said the record of the A.T.S. was a good one. The examination of recruits for the A.T.S. had since June been taken over by the Ministry of Labour. If the woman doctor conducting the examination noticed any physical indication of venereal disease or was given a suspicious history, the recruit was referred for further examination. Recruits were again examined, primarily for the purpose of cleanliness, by women medical officers. Any case of venereal disease was referred for treatment, but if not yet finally approved the woman was not admitted into the Service. It was very difficult to guarantee that every case of latent syphilis or gonorrhœa was detected ; in fact that would be impossible anywhere. It was only when symptoms showed that the matter was of public health importance. Personally she doubted whether in the communal life in which the women lived, in dormitories, with fairly public ablution places and very few facilities for privacy, acute gonorrhœa or syphilis could be concealed.

The suggestion had been made that infected women of the Services should attend civilian clinics, but that had not proved a practical proposition because the women on their stations had no ordinary dress to attend in. Further, from an administrative point of view, it was very difficult to communicate with the clinics or to follow relapses without a breach of secrecy. Therefore the plan had recently been adopted of having a V.D. ward at a large military hospital under a V.D. specialist, where many other A.T.S. attended and where there could be no stigma. A girl who had been passed for cure and observation was posted to a nearby unit so that she could attend the same specialist as long as necessary, again without stigma. That ward was opened in May, but only four members of the service were now under treatment.

Every soldier was asked to mention the source of his infection, and if he mentioned a woman of the A.T.S. she was then interviewed, first by her own lay officer and if necessary by a medical officer, and it was suggested to her that it was desirable in her own interests and in the interests of the service that she should submit to examination and tests. There had been no case of refusal so far. There had been only 5 cases of proved infection of a soldier by a member of the A.T.S. All officers and all N.C.O.'s got a lecture on V.D. But they did not lecture recruits directly on venereal diseases. These were a mixed batch, with different social backgrounds, and would make an impossible v.D. 


\section{BRITISH JOURNAL OF VENEREAL DISEASES}

audience for a lecture. It was preferable to deal with them through their N.C.O.'s. Talks were given to women, once they had joined their units, at the request of their officers.

One final word about the country clinic. Dr. Rorke had the great advantage in dealing with the wives that she was a stranger to them ; there was a great advantage in having someone besides the local general practitioner whom these women could attend. Women were more confiding to a stranger. There was a strong case for country clinics as well as for treatment by rural general practitioners.

Dr. SHANSON asked whether it was not a fact that if anybody could be shown to have knowingly conveyed infection to another person, he or she was liable to be prosecuted for a criminal offence. He thought it came under the heading of " assault."

Lt.-Col. FAIRFIELD said that in suspicious cases the difficulty was that a decision had to be made within a reasonable time. The difficulty of giving a decision after one or more examinations was fully appreciated, and she thought Colonel Osmond would agree that they did all they could once the accusation had been made, and that the test was a really thorough one.

As to lecturing, she could not agree with Surgeon-Commander Coulter. She was the last person to evade the responsibility of lecturing - the only point was one of tactics, how and when it was best to disseminate this knowledge. She felt that mere knowledge of venereal disease was of much less importance in determining exposure to infection than had been commonly made out. It was the responsibility of lay officers to have a good moral tone in their companies. The officers were told that any incidence of venereal disease was a reproach to the regiment, and it was part of the officer's responsibility to see that the women had a high ideal of good conduct and every kind of wholesome recreation. In the new regulations for the A.T.S. there was an order to be brought to the notice of every recruit on joining the unit that all cases of infectious or contagious disease or suspicion thereof were to be notified at once to the superior officers or to the medical officer. She herself was in favour of a carefully guarded measure of compulsion, but the many difficulties had not been ventilated at the meeting.

Wing Commander J. M. Kilpatrick, R.A.F., said that in the W.A A.F. the experience had been the same as in all the women's services-almost negligible V.D. From the point of view of the R.A.F. at home, he found that in I930 the ratio of syphilis to gonorrhœa, taking primary case to primary case, was $I$ to $9^{\circ} 6$, and the actual incidence of syphilis per I,000 men during that year was I.5. In I937 the ratio was I to Io, and the actual total incidence of syphilis 0.7 per thousand. In I938 the ratio was I to I2, and the syphilis incidence $0 \cdot 6$. The year I939 was a year of transition, and the figures were perhaps better omitted. In I940 the ratio was I to I3, and the actual incidence of syphilis was 0.30 per 1,000 . The total incidence of venereal disease in I 940 was 6.3 per thousand. So far as methods of control were concerned, he thought these had been amply described already.

Lieut.-Col. KING asked whether he understood Col. Fairfield to have said that latent infections were not important from the public health point of view.

Col, FAIRFIELD said that what she had put forward was that they 260 


\section{VENEREAL DISEASES IN ENGLAND AND WALES}

could not be responsible for them in examination-they could not be responsible for watching out and finding them.

Col. KING said that latency of acute infection in women in the early stages was frequent and was the crux of the whole matter. It was one important reason why it was so difficult to get women to come early for investigation and treatment. After urging infected men to write to their wives advising them to go to the clinic, one was frequently told, " I have written my wife, and she says there is nothing the matter with her, and she will not go "- - or she might go to her own doctor, who said there was nothing wrong with her. One of the troubles was lack of knowledge and faulty medical education. Some medical practitioners seemed not to understand that women might be infected with early gonorrhœa or syphilis and show few or no signs of the disease. They did not realise that in order to establish the absence of gonorrhœa, after transference of infection was alleged, a whole series of tests might be necessary.

Surgeon-Commander Coulter said that he had been most impressed by what he had heard to-day, and it was gratifying to know that progress had been made in coping with venereal diseases in this country. $\mathrm{He}$ did not think that venereal diseases constituted any menace in his own service. Yet it was distressing to see men who were incapacitated as much by an evening ashore as their colleagues in a neighbouring ward were incapacitated by wounds by mine or torpedo.

In dealing with a large number of such patients he enquired into the circumstances of each man's infection. The naval ratings were now well versed in venereal diseases and those who exposed themselves recklessly under the influence of alcohol were very rare. In most cases it meant misplaced confidence in the woman partner. Over 90 per cent. could be traced to amateurs, and in one port only 3 per cent. were traceable to professional prostitutes. The social standing of naval ratings varied very much, therefore the social standing of the infected contacts was equally varied and covered all walks of life, from the kitchen maid and shop girl upwards. Few of these unfortunate girls knew of their own infection, and, worse still, they had never heard the words " venereal diseases," and if they did hear them they would have no idea of their meaning. He ventured to state that in spite of her modern sophistication and her splendid emancipation the modern young woman was as ignorant of this subject as her great grandmother. Young women must be educated in the subject of venereal diseases and all that it implied. They must be educated in their schools and homes, and no allowance must be made for the social type. $\mathrm{He}$ realised fully the barriers that had to be surmounted, but there was a golden opportunity in this war for progression. The national movement must be stimulated by every known method of propaganda, and such education should be organised now to take its important place in post-war reconstruction.

Dr. P. C. P. InGRam said that it might interest the meeting to have some figures from a provincial centre. At his clinic the new cases of syphilis were as follows :-

\begin{tabular}{|c|c|c|c|c|c|}
\hline & & & Total & & Early Cases \\
\hline I939 & . & . & 55 & $\ldots$ & 13 \\
\hline I940 & . & . & 64 & . & I6 \\
\hline I94I & . & . & 87 & $\ldots$ & 34 \\
\hline
\end{tabular}




\section{BRITISH JOURNAL OF VENEREAL DISEASES}

This was a clinic holding four male sessions a week in a fairly busy seaport and he had been impressed by the increase in the number of foreign seamen. At a clinic of course a foreigner often impressed himself on one's mind, particularly if he could not speak English. But especially since July of last year there had been a large increase of Scandinavian and Belgian seamen.

For gonorrhœa the figures were less striking :-

$\begin{array}{lllllll}\text { I939 } & \cdot & \cdot & \cdot & \cdot & \cdot & \text { I74 } \\ \text { I940 } & \cdot & \cdot & \cdot & \cdot & \cdot & \text { I58 } \\ \text { I94I } & \cdot & \cdot & \cdot & \cdot & \cdot & \text { 20I }\end{array}$

Dr. David Nabarro hoped that the optimism expressed would be justified in the future, because we knew that in the past wars had always been associated with an increase in the incidence of venereal diseases, and the aftermath passed on to the next generation. The President had referred to the decline in the death-rate of infants from syphilis. He did not believe that anything like the actual number of cases of congenital syphilis were notified as such to the Registrar of deaths, also he considered that syphilis in infants was now much less common than in the past because of the partial treatment of the parents. During the last war the treatment of infected soldiers was much less thorough than at the present time. Perhaps six injections were given.

The PRESIDENT said ten injections of each type.

Dr. NABARRo said that even if ten injections were given it was now known that ten injections would not effect a cure and that there would be a relapse after a time, when the man would be able to inject his wife with a mild infection. The result was that the child born showed no obvious signs of congenital syphilis but had latent syphilis. That had been brought home to him when he came across some mothers born during the last war, and it occurred to him that possibly their latent syphilis was explained by a small amount of treatment in the father.

As regards prevention, it ought to be possible to get hold of these young prostitutes who were a source of infection to a number of men. The prostitute might, he supposed, be prosecuted for soliciting, and in that way put into hospital for treatment. The majority should have prior consideration to the minority.

So far as numbers were concerned, obviously the cases had been far fewer in this war than in the last, but there was no doubt that the prevention of congenital syphilis should be our aim, and he felt that they should be empowered to test the blood of every expectant mother, and if found positive treat her.

Dr. McLachlan said that at his clinic in 1937,64 males and 22 females were treated for early infective syphilis-i.e. under one year's duration. In the following year the respective figures were 83 and 22 . In I940, the first complete year after mobilisation, there were IIo males and 57 females, and for the first half of I94I, 9I males and 37 females. This indicated a moderately rapid increase of early infective syphilis in the civil population (he had excluded any service cases). Assessment of the real effect of the present increase could probably only be made from the incidence of congenital syphilis during the next few years.

With regard to gonorrhœa the figures were strikingly different. In I937 there were 788 males and I44 females, and in I940, 620 males 262 


\section{VENERFAL DISEASES IN ENGLAND AND WALES}

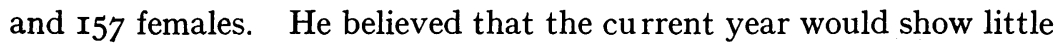
alteration. The explanation was probably the increased treatment of gonorrhœa by the general practitioner. Many women complaining of discharge were treated by their doctor with oral tablets, probably sulphapyridine. If the discharge did not clear up, stovarsol was next tried : if this failed they were then referred to the clinic. Generally no pathological tests had been taken, and the original diagnosis remained a matter of speculation. There were large numbers of women whom nothing short of force would bring to the clinic. Some of these might be influenced to attend by the police or other social agencies, and might attend for a time, but, in general, defaulted early or transferred to other areas. In his opinion the only way of dealing with this problem was by some element of compulsion in contact-tracing and treatment.

Wing-Commander G. L. M. McElligotT said he agreed with Col. Osmond on the curtailment of leave after venereal disease. $\mathrm{He}$ thought it shocking to penalise the soldier, sailor or airman on that ground. It would lead to concealment, of which there was remarkably little at present. Also, having regard to the efficacy of modern treatment, he thought that a case which was in an infectious condition when it left the service clinic was so rare that it could almost for practical purposes be discounted.

He was now convinced that the high proportion of relapses in outpatients met with in civilian practice was because they did not take the tablets as ordered and that a high initial dose was in most cases out of the question. There would always be problems in out-patient civilian clinics with an unpleasant drug such as sulphapyridine.

$\mathrm{He}$ agreed with Col. King that women with acute gonorrhœa did not as a rule spread the disease. Those responsible had little or no urethritis and little muco-purulent discharge from the cervix, and, of course, it was often difficult to prove infectivity without repeated bacteriological examinations. It might take as long as three months to establish that a woman had got gonorrhœa-certainly as much as a month, because she might produce gonococci only at about the time of the catamenia. It followed therefore that where a man had been infected by a woman and was told to get in touch with her, and did so, she might easily go to a doctor and be told that there was nothing the matter with her and quite as often if she attended at the hospital she might obtain the same absolution.

Lt.-Col. Fairfield had said that the infected A.T.S. girl was reported first to her lay officer, by whom she was tactfully interviewed. He did not know how the law stood on that, but he could not agree with the practice which seemed to offend all the canons of professional relationship.

The PRESIDent said that he would like to join issue with Dr. Nabarro in his criticism of the treatment given in the last war. Although much less than would now be considered necessary, he believed it did cure the great majority of those to whom it was administered, and this was accountable for the low incidence of late effects. He gathered from the discussion that there was a good deal of feeling, perhaps definitely a majority opinion expressed at that meeting that something ought to be done to compel the recalcitrant contact-he said " contact" advisedly, for he did not want to refer 263 


\section{BRITISH JOURNAL' OF VENEREAL DISEASES}

to one sex or the other-to undergo examination and/or treatment by a specialist. If that was the feeling, would the meeting consider instructing the Secretary to write to the Chief Medical Officer of the Ministry of Health saying that at a discussion on this subject that kind of feeling was expressed?

Colonel OSMOND and Dr. NABARRo supported such action.

Dr. Shanson said that this subject was suitable for a special meeting.

Lt.-Col. FAIRFIELD raised the question of malicious accusation. The subject was surrounded by difficulties of that kind. She hoped discussion on the subject would be ventilated.

The PREsident said that he was not thinking of detailed proposals. Of course "malicious accusation" came into one's mind. But there was a fair amount of feeling expressed that if the position could be safeguarded in some way it might be very useful to ask for some measure of compulsion.

Squadron-Leader MACGREGOR said that he had been working in a large garrison town in Lancashire where there had been a large number of cases, and it had been impossible to control the infection on the women's side. There must be several hundreds of women in that town who were apparently healthy but in fact contagious. $\mathrm{He}$ had approached the medical officer of health with a view to getting some kind of co-operation, but the only kind of co-operation appeared to be to call in the police and put the people in prison. That was not really the kind of co-operation those present would want.

The President said that he thought there was not enough unanimity as yet to justify an instruction to the Secretary to write in the way he had suggested, but he thought he could himself say that there was a strong feeling-even a very strong feeling-in favour of the proposal.

\section{IX \\ CORRESPONDENCE}

DEAR SIR,-I have recently read with great interest the paper on "Blood-Dyscrasia " in the British Journal of Venereal DisEases, January-April, I94I, and in particular the section dealing with the sulpharsphenamines and their several suggested formulæ. As I have conducted a large amount of research work on these products may I be permitted to offer one or two observations.

In the first place work in these laboratories and in France seems to show that certain sulpharsphenamines (e.g., sulfarsenol) are mixtures of the compound represented by formula $E$, with sodium formaldehydebisulphite. This latter substance is stated to be comparatively nontoxic.

In view of the remarks regarding the brands in which both aminogroups were closed might I record that I have repeatedly attempted to prepare the mono-substituted compound (formula D), but in 